Letrônica, Porto Alegre, v. 7, n. 1, p. 452-474, jan./jun., 2014

\title{
INSPIRAÇÃO, TRABALHO TÉCNICO E MEMÓRIA NO LIVRO DE SONETOS, DE JORGE DE LIMA
}

\author{
INSPIRATION, TECHNICAL WORK AND MEMORY IN THE LIVRO DE SONETOS, \\ OF JORGE DE LIMA
}

\author{
Luciano Marcos Dias Cavalcanti*
}

\begin{abstract}
Resumo: Pretendemos estudar nesse texto como Jorge de Lima se utiliza da inspiração (o onirismo como elemento que propicia o impulso poético), do trabalho técnico (o apuro da linguagem pelo exercício poético) e da memória (da infância e em seu sentido ancestral, proveniente da figa mítica da Musa) para a elaboração do Livro de Sonetos, elementos que revelam a concepção poética de sua lírica final.
\end{abstract}

Palavras-chave: Poesia brasileira; Jorge de Lima; Inspiração; Trabalho técnico; Memória.

Abstract: We intend to study in this text as Jorge de Lima if it uses of the inspiration (the dreamlike is the element which provides the poetic impulse), the technical work (the plight of the language by the poetic exercise) and the memory (from childhood and in his ancestral sense, from the mythical Muse figure) for the elaboration of the Livro de Sonetos, elements that disclose the conception poetical of its lyric end.

Keywords: Brazilian poetry; Jorge de Lima; Inspiration; Work technical; Memory.

Após a sua segunda fase, de poesia descritiva, clara e simples de cunho regional, representada pelos livros Poemas (1927), Novos Poemas (1929), Poemas Escolhidos (1932) e Poemas Negros (1947), Jorge de Lima passa a construir seus versos de forma penetrante, ou seja, o autor valoriza o "por dentro" do poema, opondo-se à descrição da coisa observada, dos acontecimentos ou cenas que a memória reteve. A palavra passa a ser o elemento privilegiado do poema. Esse tipo de perspectiva para a construção do poema insinua-se em Tempo e Eternidade (1935) e se aprofunda em $A$ Túnica Inconsútil (1938) e em Anunciação e Encontro de Mira-Celi (1943), mas se realiza amplamente no Livro de Sonetos (1949) e, sobretudo, em Invenção de Orfeu

\footnotetext{
* Doutor em Teoria e História Literária IEL/UNICAMP. Professor do Mestrado em Letras da Universidade do Vale do Rio Verde. bavarov@terra.com.br
} 
(1952). Momento em que vemos um engenhoso trabalho poético que "dá a medida exata da linguagem e que reúne todas as outras, combinando o onírico, o apelo social, a angústia metafísica, a reflexão mística com o expressionismo e a reiteração barroca." (ARAÚJO, 1986, p.29).

A poesia de Jorge de Lima, de maneira didática, pode ser dividida em duas grandes vertentes: a primeira se caracteriza pelo caráter mimético, na qual o poeta, principalmente, descreve um ambiente regional; a segunda se configura pelo processo de interiorização pelo qual passa sua poesia. De acordo com Waltencir Dutra, o procedimento formal que possibilita esta transformação nos permite refletir sobre os diversos modos do fazer poético limiano.

À medida que o poeta se interioriza, deixa de ser conceituoso para ir-se tornado imagístico, e o que é mais importante, vai substituindo o símile pela metáfora. A diferença entre eles é bem característica; o símile é uma comparação que permanece separada da experiência do poeta, existe em si e tem com o poeta uma ligação puramente acidental; a metáfora, pelo contrário, é a integração da experiência e da comparação, o sentimento do poeta se materializa naquilo a que se compara. (DUTRA, 1997, p.150).

A objetividade presente em sua "primeira poesia" é deixada de lado no momento em que o poeta troca a perspectiva descritiva e exterior por uma abrangência maior, a do mundo interior. Dessa forma,

a infância, o Nordeste, a Igreja, todos os grandes motivos, "as grandes e belas palavras" que o poeta fora escolhendo ao longo de sua vida retornam agora com a maturidade, num movimento inverso - brotam do poeta para a vida, retornam, por assim dizer, marcadas por um sentimento poético, por uma interpretação que antes não havia, o que consequentemente demandaria uma linguagem diversa da usada anteriormente - a força interior com que as recordações, a experiência do poeta, voltam ao exterior, modeladas palavras, enriquece-as de sentido. (DUTRA, 1997, p.151-152).

O momento histórico por que passa a poesia no Brasil também é sentido na mudança da perspectiva adotada por Jorge de Lima. Nos anos 40, há no país um grande interesse pelo onirismo ou pela chamada "linguagem noturna", como é notadamente percebida até mesmo na poesia de João Cabral de Melo Neto, que compôs o seu livro Pedra do Sono e "Considerações do poeta dormindo". É nessa década que Jorge de Lima publica o seu livro de fotomontagens: Pintura em Pânico (1943), - realizadas por meio do procedimento da montagem de elementos díspares, recurso proveniente do surrealismo -, Anunciação e Encontro de Mira-Celi e o Livro de Sonetos. Nessa 
perspectiva, a retomada do soneto por Jorge de Lima é realizada de uma maneira renovada, distanciando-se do modo parnasiano inicial, transcendendo àquela construção formal em que o poeta procurava retratar o mundo que o cercava por meio de uma lente "realista" e por uma forma poética pré-estabelecida. Nesse momento, o poeta pretende explorar as profundidades do interior humano pela palavra poética, que transfigura o mundo vivenciado por ele por meio do sonho, da fantasia, da memória e das metáforas complexas. 0 poeta está livre das amarras parnasianas, sua expressão poética se amplia enormemente e o poeta atinge um dos pontos mais altos de sua poesia.

O Livro de Sonetos foi saudado por Fausto Cunha como "o mais importante lançamento poético de 1949", isto porque, segundo a concepção do crítico, este livro revela dois fatos importantes para o cenário literário brasileiro: a própria relevância para a poética de Jorge de Lima - um grande autor de nossa literatura -, como também para a própria "evolução de nosso Modernismo" (CUNHA, 1958, p.559). Nesse livro, o que há de mais característico é o modo como o poeta se utiliza da palavra, que segundo Fausto Cunha, “atinge alto grau de valorização, próximo do encantamento, do virtuosismo, da abstração rítmico-sonora, (...)” (CUNHA, 1950, p. 560).

De acordo com José Fernando Carneiro (1958, p.48-49), crítico e amigo de Jorge de Lima, a composição de Livro de Sonetos e Invenção de Orfeu se deu em um momento de recolhimento do poeta por causa de um "esgotamento nervoso". Seguindo orientações médicas, o poeta se refugia para uma clínica de repouso no Alto da Boa Vista, onde compõe, em dez dias em estado hipnagógico, 102 sonetos, sendo que 77 formam o Livro de Sonetos e os 25 restantes aguardam a composição de Invenção de Orfeu, para serem incluídos neste. Situação que revela uma semelhança composicional nos dois livros. Soma-se a isso, a declaração do próprio poeta sobre a feitura de Invenção de Orfeu: "Durante dois anos fui escrevendo o poema sem saber onde ia chegar, de quantos versos constaria, nem o que pretendia. Com a sua leitura depois de composto é que verifiquei a sua intenção independente das minhas intenções.(...) Foi feito como criação onírica." (LIMA, 1958, p.94). É nessa direção que o poeta concebe sua poesia final.

É bem provável que o jorro de palavras, imagens e símbolos de que dão formas ao Livro de Sonetos e a Invenção de Orfeu possam ser considerados uma espécie de 
liberação de um repertório guardado no íntimo do poeta, que em um momento de febre e inspiração intensa foi manado verbalmente formando o poema. É claro que após este transe profundo o poeta reviu seu texto. A esse respeito é preciso lembrar que Jorge de Lima, como poucos, dominava desde sua juventude a arte do verso - um exímio sonetista -, ele poderia construir vários dos poemas pertencentes ao livro de maneira satisfatória, já na primeira materialização no papel ou mesmo com poucas modificações, pois tinha a seu favor o conhecimento técnico e a inspiração amalgamada em si. Dois elementos que, em tese, facilitariam a feitura do poema. Estes dois componentes (inspiração e trabalho técnico) somados à memória, percorreram toda a obra de Jorge de Lima, que na sua expressão maior une poesia, vida e sonho, procedimento que o aproximaria da estética surrealista. A preocupação formal na realização do livro pode ser notada, como apontou Fausto Cunha, "no largo uso do decassílabo", em que o poeta quase esgotou "as possibilidades". Aplicando, "senão todas, quase todas as combinações possíveis de rimas 'parnasianas', (...)" (CUNHA, 1959, p.562). Outro ponto importante está na própria forma que escolheu para realizar sua expressão poética, o soneto. Forma fixa e sintética em que o poeta luta contra as amarras do verso medido, libertando-os com o uso largo da metáfora, de sua imaginação, da memória e da ambientação mítica. 0 soneto pode ser encontrado em todo percurso poético de Jorge de Lima, desde os sonetos parnasianos, compostos no início de sua carreira poética até os presentes no próprio Livro de Sonetos e nos que compõem Invenção de Orfeu. Pode-se também notar no Livro de Sonetos, um certo "neossimbolismo", tendo como ponto de "ressonância" o poeta Cruz e Souza, "a valorização do adjetivo, (...) a busca da sonoridade" (CUNHA, 1958, p.563). É que, segundo o Fausto Cunha, "no Livro de Sonetos o emotivo foi amiúde quase substituído pelo ourives do verso." (CUNHA, 1958, p.564) Situação que faz o crítico afirmar que "em mais de um momento no Livro de Sonetos o autor enveredou pelo caminho do cerebralismo e exerceu verdadeira tirania da forma sobre o conteúdo." (CUNHA, 1958, p.564). Características que revelam o hermetismo do livro. Nesse sentido, o poema limiano é elaborado através da comunhão (talvez, para alguns, paradoxal) entre a inspiração e o rigor formal.

A lírica de Jorge de Lima se associa aos grandes nomes da poesia moderna universal: Baudelaire, Rimbaud e também Mallarmé, já que o poeta brasileiro é ousado 
na utilização de metáforas complexas, negando-se a representar o mundo de maneira clara e fácil. O que ele deseja é criar novas realidades através de uma nova representação literária, feita pela imaginação e pela própria poesia. Como nos aponta Fábio de Souza Andrade, a última fase de Jorge de Lima se inclui nessa tradição, pois o poeta

emprega largamente a metáfora absoluta, as metáforas genitivas, abertas para a ambiguidade e pluralidade de sentidos. Muito mais do que simples construção metricamente peritas ou demonstrações de habilidade poética, seus sonetos finais - os do Livro de Sonetos e da Invenção de Orfeu - são experiências-limite dentro dessa vertente moderna da poesia. A obscuridade semântica aparece aqui como defesa possível contra a banalização das palavras e da própria lírica. A estratégia é fechar-se a si mesmo para sobreviver, criar carapaças (i.e., as imagens complexas) que dificultam a compreensão imediata, mas preservam o que é, por natureza, forte e frágil: a capacidade da linguagem de fundar mundos próprios. (ANDRADE, 1996, p.138).

O poeta mesmo reflete sobre esta perspectiva, apontada acima, associando-se ao pensamento de Mallarmé, Valéry e T. S. Eliot, quando preconiza que na linguagem poética "os poetas devem primar pela concisão e pela justeza verbal." Mas os poetas não podem se esquecer "de que devem comunicar aos outros a sua poesia e não sobrecarregá-la de tal obscuridade que torne incompreensível. A dificuldade da linguagem poética reside precisamente nisso: ser linguagem do poeta e ser comunicável”. (LIMA, 1958, p.73). Muitas vezes acusado de hermético, Jorge de Lima tinha consciência de que o poeta tem que se comunicar com o leitor; caso contrário, sua poesia estaria fadada ao fracasso, ficaria presa em si mesma. No entanto, há de se considerar, como aponta Álvaro Lins, de que muitas vezes não é responsabilidade do poeta essa não transmissão de sua experiência poética: “A responsabilidade pode se encontrar no leitor, no seu prosaísmo, nos seus preconceitos, nas suas exigências de uma clareza dentro da lógica comum. A poesia moderna, porém, se acha colada muito além dessa lógica comum." (LINS, 1970, p.20). O crítico salienta ainda que "algumas obras têm o destino de conservar um estado de mistério, de se concentrar dentro de uma espécie não comum de obscuridade." (LINS, 1970, p.21).

O Livro de Sonetos é comumente considerado uma espécie de introdução à Invenção de Orfeu, há uma série de poemas em que Jorge de Lima desenvolve a arte poética característica da perspectiva órfica encontrada em seu poema "épico". Neste livro, o que o poeta faz é, na verdade, uma desarticulação da linguagem poética 
assimilada por toda uma geração neo-parnasiana, desfazendo-a e criando uma nova perspectiva para o discurso poético, preponderantemente moderno. Assim, segundo a perspectiva de Fábio de Sousa Andrade, "contra o pano de fundo dos ruídos de um mundo que já nada nos diz de novo" faz com que o poeta recolha "um punhado de imagens partidas' (Eliot)" e infunda "nestes fragmentos um novo sentido internamente: a utopia possível na distopia presente." (ANDRADE, 1997, p.112).

A "evolução" poética de Jorge de Lima se fez sempre num sentido cada vez mais metalinguístico e interiorizado. No início de seu percurso literário, o poeta se utiliza dos motivos infantis e regionais, passando para os temas religiosos e sociais, para logo após no Livro de Sonetos e Invenção de Orfeu, se dedicar prioritariamente à subjetividade da vida interior, apoiado na habilidade técnica e na imaginação poética. A palavra poética no Livro de Sonetos atinge alto grau de valorização, próximo do encantamento, do virtuosismo, da abstração rítmico-sonora, em que o jogo poético se realiza plenamente.

É notável a aguda coesão no Livro de Sonetos, que pode ser notada na recorrência do onirismo como procedimento de criação poética, na inspiração, nas metamorfoses de objetos que compõe o poema, a inter-relações de reinos - o líquido, o aéreo, e o sólido, no seu caráter metalinguístico, no uso da fantasia, na presença de imagens complexas - procedimento usado para revelar uma realidade fugidia e mesmo insólita. Talvez um fato que explique esta forte unidade do livro esteja também no próprio modo em que o livro foi elaborado, como já dissemos, em estado de hipnagose, em um só jato. Para Ana Maria Paulino, o Livro de Sonetos pode ser considerado o ponto alto da poesia de Jorge de Lima, contrariando a critica em geral, que acre dita ser Invenção de Orfeu o ocupante desse lugar. Para a ensaísta diferentemente do épico limiano, que "mereceria, por parte do autor, revisão e cortes" (PAULINO, 1995, p.64) o Livro de Sonetos é, ao contrário, "conciso". Livro em que Jorge de Lima "cria os mais elaborados sonetos" (PAULINO, 1995, p.66).

Essencialmente metalinguístico o Livro de Sonetos revela o procedimento poético utilizado pelo poeta para sua construção, como também a sua matéria.

\footnotetext{
E são setas do céu (Ó sagitário!).

Versos brotam de mim. Depois de lidos os distribuo por um destino vário, depondo em seus percursos meus sentidos.
}

Exijo que eles sejam meu sudário. 
Reconheço-me: aqui os meus gemidos, e ali esse vulcão desnecessário, jogando lava em todos os sentidos.

Que chegar de presenças! Que contagio! Que pajens anunciados e banidos! Nos bosques sugeridos - que presságio!

Perscruto-me nos verbos nunca ouvidos, Apenas pressentidos ou passados. Ó bosque ermo de pássaros calados!

O primeiro quarteto desse soneto revela o procedimento poético de Jorge de Lima, que em uma inspiração intensa recebe a poesia de uma entidade superior, que habita no céu: “E são setas do céu (Ó sagitário!).”. O poeta é uma espécie de semideus ou um eleito, que recebe gratuitamente do divino sua inspiração poética, - mas esta inspiração se misturada a sua própria angustia de existir - para posteriormente organizá-la à sua maneira: "Versos brotam de mim. Depois de lidos/os distribuo por um destino vário".

Em seguida, viemos, a saber, que a inspiração também é proveniente de uma dor por que passa o poeta: "Reconheço-me: aqui os meus gemidos,", mas a poesia (seus versos) é seu manto protetor: "Exijo que eles sejam meu sudário.". Assim no primeiro terceto é revelado que o poeta é uma espécie de profeta, um ser iluminado: “(...) - que presságio!" 1.

0 que vemos no último terceto é a relação direta do texto literário com o mito. 0 que pode ser notado pela sondagem do poeta aos "verbos nunca ouvidos" ou muito distantes do presente, provavelmente do momento da criação, o verbo original: "Apenas pressentidos ou passados.". De acordo com essa perspectiva, é pela poesia que o poeta deseja vivenciar os momentos de um mundo inicial. Esse aspecto é notado não só por seu desejo de voltar ao passado, mas também pelo desejo de encontrar a palavra -

\footnotetext{
${ }^{1}$ Raymond nos explica a distinção entre o poeta e o místico. Para ele: "o poeta é aquele que cria, que faz um objeto cuja matéria é a linguagem, e que essa intenção de fazer é o princípio que orienta e unifica seus poderes. (Mas, o poeta, comprometendo-se por inteiro com outros poderes que não os da inteligência fabricadora transgride inevitavelmente seu objetivo; engendra um ser microcósmico que tende ipso facto a reproduzir analogamente o grande 'mundo', sentido ou pressentido por ele de forma obscura). Desse ponto de vista, discerne-se melhor qual tentação assalta os modernos: a de querer alcançar imediatamente o Absoluto, por uma experiência que quase se confundira com a dos místicos, para encerrá-la em alguma imagem ou símbolo. Assim Baudelaire falava de raptar o paraíso de uma só vez. Mas o 'conhecimento' poético, ou o chamado assim, acompanha a experiência; ela lhe é consubstancial; e a experiência do que se trata é a do criador.". (RAYMOND, 1997, p.310).
} 
especial, rara -, que ainda não foi pronunciada ou proferida no momento da criação, mítica e fundadora. 0 verbo novo, como o original em que a palavra é dita pela primeira vez e, portanto, nomeia as coisas fazendo com que elas passem a existir. Parece ser este o ideal do poeta, fundar um mundo novo, semelhante ao original e divino, por meio da revitalização ou da criação de um novo verbo, pela linguagem poética.

No soneto seguinte podemos notar a reafirmação do que vinha sendo dito. Nesse poema, de forma bastante explícita, vemos que a sua feitura é realizada pelo trabalho de livre associação de ideias, aparentemente sem nexo. 0 poeta reivindica explicitamente uma poética noturna, mais profunda do que a poética diurna, estritamente racional. Pois é nesse mundo profundo do sono que se pode notar os "seres ignorados" e, porque não, tudo que é ocultado no mundo da superfície, da aparência. 0 que revela no poema também uma forte perspectiva social, somado ao próprio mundo existencial do poeta que inserido no mundo moderno sente o caos presente.

O poeta "antena da raça" é o ser capacitado de sensibilidade para vislumbrar os "seres das sombras", aqueles que não são visíveis aos olhos do mundo diurno, ordenado pelo "estabelecimento". O poeta resiste as imposições desse mundo o qual não tem olhos para aquilo que não o realimenta. Eles são os últimos a se calarem, imitação de Deus, assume sua voz para clamar justiça e reordenar (recriar) o mundo. Quando nomeia, pela força do verbo, como um demiurgo, o poeta cria um novo mundo mais solidário, similar ao da arte.

\footnotetext{
Não procureis qualquer nexo naquilo que os poetas pronunciam acordados pois eles vivem no âmbito intranquilo em que se agitam seres ignorados.

No meio de desertos habitados só eles é que entendem o sigilo dos que no mundo vivem sem asilo parecendo com eles renegados.

Eles possuem, porém, milhões de antenas distribuídas por todos os seus poros aonde aportam do mundo suas penas.

São os que gritam quando tudo cala, são os que vibram de si estranhos coros para a fala de Deus que é sua fala.
} 
A memória será um elemento frequente e extremamente importante para a elaboração poética de Jorge de Lima. Ela se configurará de maneira exemplar na figura ancestral da musa. Situação que estabelecerá a estreita relação entre o texto poético limiano à dimensão mítica, no sentido de que, numa de suas fortes marcas, o poema busca uma espécie de "memória profunda" da cultura, trazendo para o presente um passado mítico perfeito. De acordo com essa perspectiva, é pela poesia que o poeta deseja vivenciar os momentos de um mundo inicial. Esse aspecto é notado não só por seu desejo de reencontrar o passado, mas também pelo próprio ritmo do poema entregue à inspiração, livre de quaisquer amarras e por suas imagens. Para isso, o poeta buscará o auxílio das musas para construir seu poema².

A memória está associada aos atos ligados à criação: inventar, medir, refletir, cuidar. É através da memória, que a unidade é revelada. Nela, presente passado e futuro se fundem. No momento em que o poeta é possuído pelas Musas, ele absorve o conhecimento de Mnemosyne, dessa maneira, ele obtém todo conhecimento expresso pelas genealogias, atingindo o ser em toda a sua profundidade. É a descoberta da origem, do movimento primordial: a gênese, o nascimento da humanidade, o surgimento do cosmos. Portanto, é por meio da memória que o poeta tem acesso ao indecifrável e consegue enxergar o invisível. Como aponta Eliade, "graças a memória primordial que ele é capaz de recuperar, o poeta inspirado pelas Musas tem acesso às realidades originais. Essas realidades manifestam-se nos Tempos míticos do princípio e constituem o fundamente deste Mundo" (ELIADE, 1998, p.108). O canto das Musas revela como o mundo e seus habitantes surgiram. Esse poder ontofânico pode ser evidenciado hoje na

\footnotetext{
2 Na Grécia antiga, a memória foi encarnada pela deusa Mnemosyne, mãe das nove musas. 0 poeta, inspirado pelas Musas, tinha a função de glorificar os fatos passados e futuros, situação que o assemelha ao profeta. É a testemunha inspirada dos "tempos antigos" e da "idade das origens". Segundo Vernant, em Mito e pensamento entre os gregos, a memória (Mnemosyne), caracterizava-se, no pensamento mítico e arcaico grego, por ter o conhecimento do Tempo: o passado, o presente e o futuro. Mnemosyne tinha, igualmente, o conhecimento do Espaço: do mundo do visível e invisível, do espaço dos vivos e dos mortos. Mnemosyne não era, como a memória, conhecimento de um tempo passado, mas, ao contrário, memória de um tempo que continua no presente e no futuro, pois é memória de um tempo arcaico (arché), primordial, original da formação e organização do mundo e do espaço. A memória mítica e arcaica, portanto, tem, segundo Vernant, a onisciência: ela vê tudo em todos os momentos. Ela está além do começo e do fim. Ela tem sabedoria suprema ao conhecer o passado, o presente e o ausente, o todo do tempo e do espaço e, como que por adição, aquilo que excede esse todo. Possuído pelas musas o poeta é o intérprete de Mnemosyne. (ver VERNANT, 1990, p.105-131). Portanto, é pela memória que o poeta consegue superar os limites determinados pela espacio-temporalidade ordinária e material e ir além do mundo sensível.
} 
experiência poética, isto ocorre quando a poesia consegue fundar uma realidade própria a ela, quando funda seu próprio mundo.

O Livro de Sonetos colocará em relevo uma das musas mais importantes de Jorge de Lima, Mira-Celi, entidade mítica que repercutirá em sua lírica final. No soneto seguinte vemos a clara mistura de contrários, a musa mesmo caracterizada como um ser marinho que habita o ar. Em um ambiente mágico, noturno e especial - que só acontece em espaços temporais raros ("em eclipse"), duplicado ("em pauta dupla"), com a presença marcante da "trilha sonora" de Bach. Em um ambiente que não é possível identificar se é noturno ou claro ("dia") em que se percebe a metamorfose da "nau" (o poema) em "pássaro" ou "navio", "pedestal" ou "altar". Em um movimento em espiral, intenso e devastador, como a própria poética de Jorge de Lima, que retrabalha de maneira renovada temas e formas anteriores, a musa, em um momento mítico, especial, único, aparece entre o horizonte e o mar. Desse modo o poema une magia, rompimento com o tempo linear, a multiplicidade de sua forma e o mito.

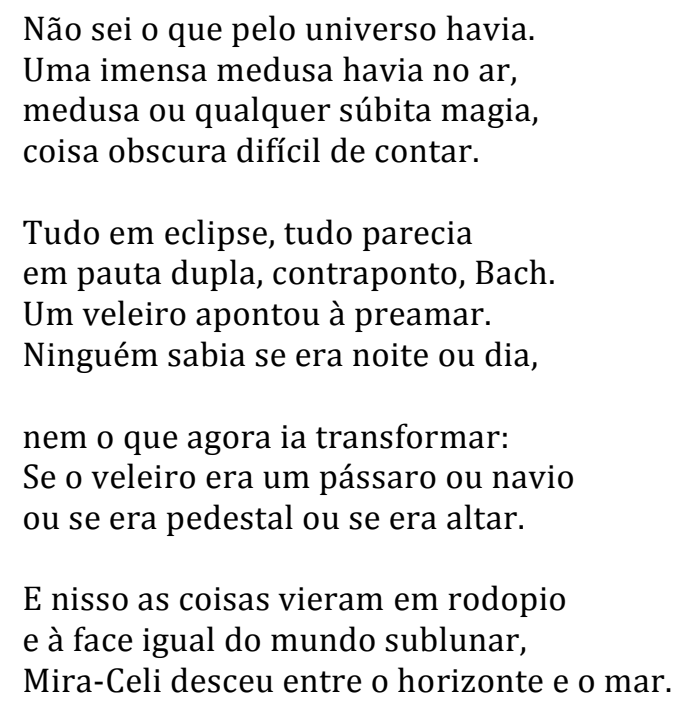

Mira-Celi é uma das musas mais significativas da poesia limiana (também marca forte presença em Invenção de Orfeu). Musa proveniente de sua poesia anterior, Anunciação e Encontro de Mira-Celi (1943), é caracterizada por sua complexidade interpretativa e à infância do poeta ${ }^{3}$. Neste livro, a criação poética estará

\footnotetext{
${ }^{3} 0$ próprio Jorge de Lima nos previne sobre a complexidade dessa musa: "Acho dificuldade de explicar à professora americana a vida de Mira-Celi. A vida, a origem, os jogos, o conhecimento dela, tudo inexplicável. Ainda menino, encontramo-nos durante uma convalescença, depois em outras, em outras depois, em momentos que não posso precisar. (...) Não procuremos exegeses a muitas respostas de MiraCeli, pois é tida como sonâmbula, e pode, devido a qualquer impertinência, perder-se todo, embora,
} 
intrinsecamente ligada à inspiração, a memória (Mira-Celi é a musa que inspira o poeta) e à busca do sagrado. É o momento em que Jorge de Lima constituirá uma relação profícua com a linguagem mística, com a estética surrealista, estabelecendo uma relação estreita com o mundo noturno, o onírico e o fabuloso, propiciando à imaginação, a magia e a inspiração em sua poesia. Ela será o leitmotiv de sua poesia, como podemos ver nos primeiros versos de seu poema número "2": “Tu és, ó Mira-Celi, a repercutida e o laitmotivo/ que aparece ao longo de meu poema." (LIMA, 1958, p.507). Este livro singular em toda literatura brasileira nos revela muito do que virá adiante na poética de Jorge de Lima. É mesmo uma preparação anunciada para a elaboração de Invenção de Orfeu, que se torna evidente nos versos seguintes: "Os grandes poemas ainda permanecem inéditos." (poema "4") (LIMA, 1958, p.508); “Os grandes poemas começam com a nossa visão desdobrada" (no poema “56") (LIMA, 1958, p.552). Chama a atenção também seu caráter circular, no sentido de que seu primeiro e o último poema começam da mesma maneira como se um fosse continuidade um do outro: "0 inesperado ser começou a desenrolar as suas faixas em que/estava a história da criação passada e futura.". Esse aspecto demonstra o desejo, expresso nos dois poemas (Anunciação $e$ encontro de Mira-Celi e Invenção de Orfeu), do rompimento temporal e do encontro do poeta com a eternidade.

Como uma espécie de sequencia do poema anterior o poeta enfatiza a presença da musa em seu poema.

\author{
Pelo silêncio que a envolveu, por essa \\ aparente distância inatingida, \\ pela disposição de seus cabelos \\ arremessados sobre a noite escura: \\ pela imobilidade que começa \\ a afastá-la talvez da humana vida \\ provocando-nos o hábito de vê-la \\ entre estrelas do espaço e da loucura; \\ pelos pequenos astros e satélites \\ formando nos cabelos um diadema \\ a iluminar o seu famoso manto,
}

\footnotetext{
reapareça inexplicavelmente em todas as solidões ou em quase todos os delírios da febre. Então ide devagar, pé ante pé, porque não estais só, e se conseguires galgar esta escadaria que começa sobre vossa cabeça, alcançareis alguma noções, qualquer certeza, um encontro talvez. Pode toda esta mágica se romper, entretanto, como uma bolha; circundai cauteloso, ficai perplexo para que os últimos tetos não desabem sobre vós." (LIMA, 1958, p.501-02)
} 
vos que julgais extinta Mira-Celi observai neste mapa o vivo poema que é a vida oculta dessa eterna infanta.

A memória biográfica do tempo de criança em sua cidade natal, e um fato que marcou o poeta por toda sua vida, também é resgatada com intensa emoção lírica.

\author{
Nas marés baixas via-se uma draga \\ enferrujada, e um mastro de galeota. \\ E pousada na areia uma pressaga \\ forma que se assemelha à estátua ignota. \\ Mas, a cena renova-se, a onda a alaga; \\ e vem asas ariscas de gaivota: \\ 0 pensamento rápido naufraga, \\ tudo segue de novo uma outra rota. \\ O mar noturno é sempre mais fecundo \\ com seus veleiros cegos afogados \\ na solidão original do mundo. \\ Corvos marinhos cruzam transtornados \\ a abóboda dos crâneos insensatos: \\ Muda-se tudo, surgem novos atos.
}

Soma-se a visão surpreendente da draga que o menino via em sua infância no rio Mundaú, como uma Nau encalhada, transfigurada em uma estátua desconhecida (a maneira surrealista de De Chirico, Picasso, Braque, Dalí, etc., artistas que deixaram de representar a natureza de forma mimética para deformá-la, criando outro mundo), a misteriosa retomada do mundo fantasioso e/ou fantasmagórico da infância e a mistura entre realidade e fantasia o retrato de suas musas infantis. Nesse sentido, é visível a aproximação da poesia com a pintura surrealista, com sua fusão do real ao imaginário, o visível ao invisível, o racional ao irracional. 0 que ocorre é um desprezo dos artistas pelo mundo "sensível", pois não há mais sentido em reproduzir mimeticamente o real. 0 poema se realiza como uma composição surrealista em que os elementos opostos se misturam e se transmutam um no outro, de modo que a representação deste estado poético só poderia se realizar por um tipo de representação imagética renovada.

Assim, de maneira intensa, posteriormente o poeta traz para a elaboração de sua poesia um artefato constantemente presente em seu imaginário a "esfera armilar", símbolo da iluminação poética - e do desejo do homem conhecer e organizar o mundo - associado a infância e suas musas. Este candeeiro familiar, originalmente à querosene, tem um valor especial na poesia limiana. Acompanhou o poeta desde sua estadia em 
União dos Palmares, em sua primeira infância, até a mudança para Maceió, cidade onde já havia luz elétrica. 0 candeeiro teve que ser levado a Maceió e adaptado à energia elétrica porque as crianças da família Lima, acostumadas à luz do lampião - além de sua relação afetiva com este objeto -, só estudavam em sua presença. A presença da "esfera armilar" na poesia de Jorge de Lima é constante, já a notamos em: "O mundo do menino impossível" ("O menino poisa a testa/e sonha dentro da noite quieta/da lâmpada apagada/com ele tirou do nada [...]"); no próprio Livro de Sonetos: ("Éramos seis em torno de uma esfera/armilar. Um candeeiro antigo diante/de seus olhos.") e em "Candeeiro familiar" - Poemas dispersos -, em que a imaginação infantil transfigura o objeto em uma série de projeções de imagens.

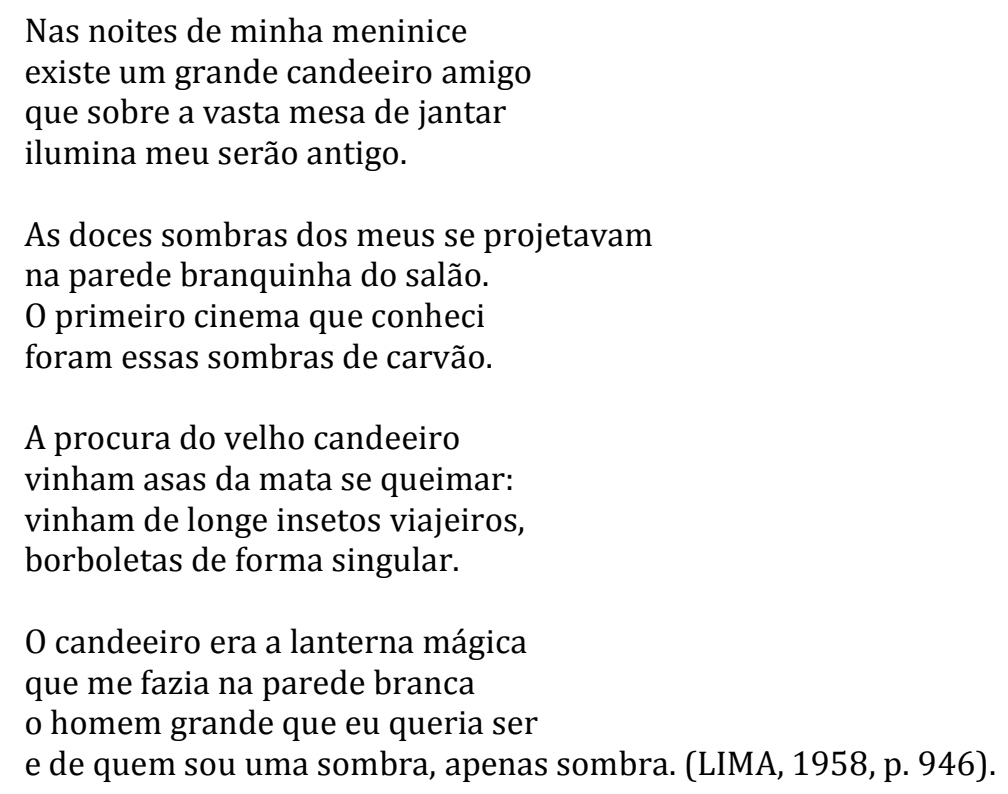

Em várias passagens de Invenção de Orfeu o candeeiro belga também estará presente: "Lemos contos de Grimm, colamos mariposas/nesse jato de luz em frente às velhas tias" ("I, XXIV"); "grandes lâmpadas, focos de falenas,/as falenas no chão sem asas." ("II, XIV"), "Falenas _ prata e luz, esvoaçar lento/em torno ao candeeiro familiar./Alguém sobre os degraus (hiato no poema,/recordação tenaz, terrível voz!)” ("V, III"); "Nesse ambiente, conhece-se um candeeiro;/éramos quantos rabiscando quadros?" (VIII), novamente no Canto (VIII), "éramos cinco, eu bem me lembro 
dessa/menina loura que se pôs a alar-se," etc. ${ }^{4}$. Este candeeiro também representa, na poesia limiana, a transfiguração do mundo infantil em poesia.

\author{
Éramos seis em torno de uma esfera \\ armilar. Um candeeiro antigo diante \\ de seus olhos. E súbito se gera \\ o vácuo na memória bruxuleante. \\ Procuro relembrar-me: seu nome era... \\ não sei se Abigail ou se Violante. \\ Sei que nos seres houve longa espera: \\ que ela não fosse estrela tão distante. \\ Passa-se o século; ignoro outros aspectos \\ do minuto que passa e do milênio. \\ Indo a uma feira vi num palco um gênio \\ com uma esfera armilar cheia de insetos \\ cedê-la a cinco crianças em disfarce, \\ e houve uma delas que se pôs a alar-se.
}

O gosto pelos saraus literários quando criança, suas experiências "sobrenaturais", imaginativas e suas leituras, já prenunciavam a tendência do poeta para o gosto da criação pela memória. Desse modo, a memória e sua representação na figura da musa será um elemento importante e frequente na poética de Jorge de Lima, significativamente no Livro de Sonetos e principalmente em Invenção de Orfeu, momento em que o poeta é amparado por uma grande variedade de musas, que estão presentes em todos os Cantos do poema, retiradas da tradição literária ou mesmo criadas por ele. No primeiro caso, são representadas por Inês de Castro, Lenora, Eurídice, Beatriz, Ofélia, Penélope, Eumetis, entre outras; no segundo, está figurada em Mira-Celi e também outras provenientes de sua infância como Francisca, Lis, Celidônia, etc.

Lis será uma importante musa que Jorge de Lima transfigurará de sua infância para sua poesia. Musa que se repercutirá também em Invenção de Orfeu (ver LIMA, 1958, p.680). Em suas "Memórias", o poeta nos fala de sua amiga da meninice, protagonista de

\footnotetext{
${ }^{4}$ Jorge de Lima nos relata a presença deste candeeiro: "garatujávamos com lápis de cor; começamos as leituras comoventes: Inocência; Graziela [...] Tínhamos livros de lições de coisas com experiências de mágicas familiares". Dessas reuniões, onde igualmente se distraíam com "artes ocultas", além do irmão José Matheos, participavam outros companheiros: Antoninho, Gustavo, João Moreira, Zé Peluzio, Dagoberto e Lys, irmã deste último. "Vinham meninos da vizinhança atraídos pelo que se passava à luz do candeeiro. 0 círculo iluminado dourava as faces pintadas para As Mil e Uma Noites". (LIMA, 1958, p.30). Através desta nomeação dos participantes dos saraus literários que aconteciam em sua casa, feita pelo poeta, sabemos que são sete os membros participantes. Assim se esclarece a divergência quanto ao número de pessoas frequentadoras destes saraus, que hora aparece como sendo seis: em Livro de Sonetos; quatro e cinco no Canto VIII (Biografia) de Invenção de Orfeu.
} 
um acontecimento extraordinário que o marcou profundamente: Lis voando no sarau literário que acontecia em sua casa: "e houve uma delas que se pôs a alar-se." 5. Este "acontecimento" impressionou tanto o poeta que acabou por transformar a amiga da infância em musa. É interessante notar, nesse momento, a relação intrínseca entre a musa do poeta e a memória em seu sentido mítico, como já dissemos, o canto (as Musas) é nascido da Memória (Mnemosyne). É através da memória e de sua musa (Lis) que Jorge de Lima viabiliza seu canto. Esse aspecto é constante no seu poema, onde encontramos um número grande de Musas, como já dissemos, sejam elas criadas pelo poeta ou retiradas da tradição literária. Nesse sentido, o poeta tem na palavra cantada o poder de ultrapassar e superar todos os bloqueios das distâncias espaciais e temporais, um poder que só lhe é conferido pela Memória (Mnemosyne), através das palavras cantadas (Musas).

É importante notar que o primeiro contato de Jorge de Lima com a poesia provém da infância e é essencialmente lúdico. Nasce dos jogos e brincadeiras infantis, das leituras de contos e fábulas feitas por sua mãe, da própria imaginação do poeta menino ou mesmo dos primeiros contatos com a leitura, como se lê nas suas Memórias. Desse modo, podemos observar claramente que a concepção poética de Jorge de Lima se articula entre o lúdico e sua realidade infantil. É o que se nota praticamente em toda a sua poesia.

Ao retirar o poético do mundo infantil e de sua memória, vemos a tentativa do poeta em instaurar um novo mundo, revelado em seus poemas por suas imagens carregadas de emoção poética e pela busca de um sentido original para sua poesia. Portanto, o poeta cria auxiliado por inúmeras divindades. É também relevante notar que o caráter iniciático e a ligação das musas ao reino dos mortos nos apontam também para a ligação do poeta ao Simbolismo juntamente as situações biográficas de sua infância,

\footnotetext{
${ }^{5} \mathrm{Em}$ um dos momentos mágicos de sua infância, o poeta nos conta que numa ocasião em que sua mãe lia para ele e seus amigos, em uma espécie de sarau literário que ocorria em sua casa, em torno de um candeeiro belga (a "esfera armilar"), Os Estranguladores de Bengala, uma história indiana ocorre um fato fabuloso, assim conta o poeta: "Examinávamos uma esfera armilar em que havia no centro uma bola de vidro contendo mariposas que havíamos retirado da treva. E ninguém sabendo o que houve pôs-se Antoninho Gustavo a gritar alucinado: _ Lis está voando. Lis está voando. E olhando Lis e com efeito Lis estava esvoaçando como uma mariposa, em torno da esfera que encerrava a mesa; e corremos em torno da esfera e seguramos Lis pelo vestido de borboleta, e tudo parou, e mãe acudiu, e tudo voltou ao que era. Lis não sabendo o que havia acontecido começou a chorar, e seu pranto desfez em nós a grande alucinação." (LIMA, 1958, p.130-131).
} 
momento em que viu sua "amiga" (Celidônia) morrer afogada 6 . Soma-se a isso, como se vê nos dois primeiros versos, a reafirmação do fazer poético de limiano, realizado por meio da inspiração intensa, sem que o poeta possa conter tal força impulsionadora de sua poesia. Amparado por várias musas: "Lúcias", "Isas", "Celidônias" o poeta cria seu poema "sem balizas", ou seja, sem padrão, sem limite, sem fronteira ou, até mesmo, sem fim. Esse rompimento com tais padrões é proporcionado pelo "sonho" e "indecisões", elementos que nutrem o poema.

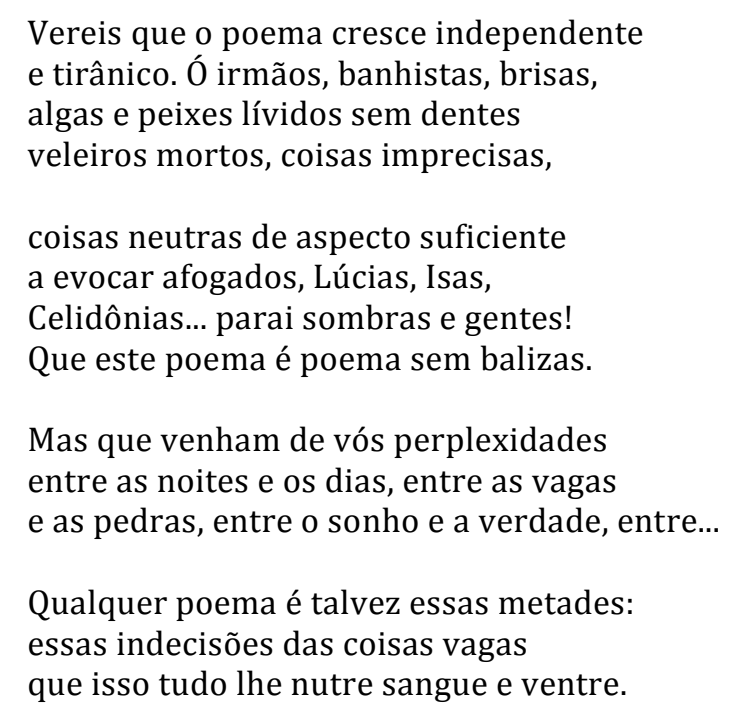

Em um poema metalinguístico, vemos a mistura da variada concepção poética limiana, anteriormente mencionadas: o verbo fluente ("Solilóquio sem fim e rio revolto"); a metapoesia, soma da inspiração com o trabalho poético ("ruminando as palavras, e escutando/o que é consciência, lógica ou absurdo."); a memória ("A memória em vigília alcança o solto"); mistura temporal do passado com o futuro ("perpassar de episódios, uns futuros/e outros passados, vagos, ondulando") e o estado em que o poeta se e contra no momento da criação e sua transfiguração no poema ("E tudo num refrão atormentado:/(...)/ postigo, esse último portão que eu abro/para a fuga completa da razão.")

Solilóquio sem fim e rio revolto mas em voz alta, e sempre os lábios duros ruminando as palavras, e escutando

\footnotetext{
${ }^{6}$ Ana Maria Paulino aponta que este tema frequente na poética limiana também se liga ao topos da "Infanta defunta", o que mostra o diálogo de seus poemas com a composição de Ravel: Pavane pour une infante défunte, inspirada pela lenda da morte da Princesa Polignac. 0 poeta também se utiliza desse tema no sentido de aproveitar o seu caráter plástico para seus poemas. (ver PAULINO, 1995, p.38-40)
} 
o que é consciência, lógica ou absurdo.
A memória em vigília alcança o solto perpassar de episódios, uns futuros e outros passados, vagos, ondulando num implacável estribilho surdo.
E tudo num refrão atormentado: memória, raciocínio, descalabro... Há também a janela da ampliação;
e depois da janela esse esperado postigo, esse último portão que eu abro para a fuga completa da razão.

De forma enfática o sono, o sonho, o devaneio e a própria multiplicidade do eu poético se mostram presentes de maneira recorrente. Nota-se neste soneto que o poeta busca cruzar a camada superficial do real com a retomada de um mundo submerso. Para isso, ele procura o sentido oculto das coisas e deseja edificar outras realidades através do imaginário e do sonho. Desse modo, com a inserção do sonho e do imaginário na poesia ela acaba se caracterizando como um espaço utópico, onde a renovação do mundo real se dá através do onírico. Isso ocorre também na questão formal do poema, quando o poeta reorganiza os significados semânticos das palavras e faz uso da metáfora complexa, deixando que o leitor perceba a linguagem redimensionada do poema e a identifique com uma reordenação das palavras de modo antes não pensado. Isto se dá justamente pelo caráter imaginativo e transformador da linguagem dos sonhos, que proporciona o encontro do poeta com esse "mundo perdido" (e/ou prometido) que é a própria poesia. Nessa perspectiva, a linguagem poética através da imaginação procura reconstruir os elementos formadores desse mundo na tentativa de recuperar o tempo da origem, anterior à queda do homem no paraíso edênico, como se pode notar em sua última estrofe.

\footnotetext{
Quando tu dormes vêm as albergálias (aves noturnas de impalpáveis penas), pousar nas tuas mãos atormentadas um viveiro de lavras epicenas.

Descem contemplações anjo-animálias com seus cálices, vinhos e patenas, descem máscaras sempre renovadas mudando-te em ator de novas cenas.

E papoulas enfeitam tua fonte, ó sacerdote de ignorado rito e de gozos com seres sem presença.
} 
Poeta dormindo, subterrânea fonte, quando gritas ninguém ouve esse grito que antecedeu teu grito de nascença.

A realização poética por meio do sonho já foi amplamente discutida pelos teóricos da arte, principalmente pelos surrealistas. Talvez, alguns poucos pontos importantes da teoria da interpretação dos sonhos de Freud possa nos ajudar a pensar sobre a maneira pela qual Jorge de Lima realiza seu processo de criação poética. De acordo com a teoria freudiana, a atividade onírica de pensar não ocorre em conceitos, como é característico do estado de vigília, mas pensa "predominantemente em imagens visuais" como também por "imagens auditivas e, em menor grau, impressões que pertencem aos outros sentidos". (FREUD, 2001, p.67). Nessa direção, o psicanalista aponta mais uma característica importante do estado onírico: "Os sonhos são desconexos, aceitam as mais violentas contradições sem a mínima objeção, admitem impossibilidades, desprezam conhecimentos que têm grande importância para nós na vida diurna e nos revelam como imbecis éticos e morais." (FREUD, 2001, p.72). 0 que mostra que a "incoerência" das imagens oníricas se revela como característica essencial dos sonhos. Outra característica do sonho se refere a seu processo de deslocamento. Isto significa que uma imagem pode ter mais de um significado, pois por analogia pode-se transferir sentimentos e conceitos de uma a outra. No sonho, percebe-se também a facilidade para o trocadilho e a inversão de termos como se as palavras se comportassem como coisas. Características estas que apontam para a semelhança entre a formação dos sonhos e a atividade artística. No seu sentido geral, as ideias essenciais do onirismo para Freud podem ser sintetizadas por duas características fundamentais da imagem poética "deslocamento" e "condensação". "Essas duas formas conectivas típicas da imagem onírica correspondem a um princípio paratático agregativo e ou comparativo analógico (próprios da metonímia e da metáfora...)." (BOSI, 2001, p.35).

Assim podemos ver, em outro soneto, o sono/sonho proporcionando o modo de construção do poema, o poeta adivinho/profeta inspirado por uma musa: "Sonâmbula" (que está em um estado intermediário, entre o sono e a vigília), a desconexão dialógica realizada também pela inspiração proveniente da musa do poeta, o movimento em espiral, que mostra a intensidade da inspiração, o estado mental perturbado do poeta e seu "diálogo sem nexo" e o rompimento com o tempo cronológico linear, em que sua 
musa ocupa e/ou participa da totalidade do tempo, o que traz novamente à poética limiana ao sentido ancestral e mítico de Mnemosyne, que conhece o passado, o presente e o futuro, a totalidade do tempo: "pois é ao mesmo tempo avó, mãe e filha". Acresce-se a isso o local sagrado de onde a musa provém, o mundo da origem, ancestral, do tempo da criação: "ressuscitada de dormidas brasas."

Dormes. Surgem de ti coisas pressagas.

ó bela adormecida, não tens sexo,

como as algas marítimas que as vagas

jogam na praia em renovado amplexo.

0 vendaval é o mesmo em que te apagas

num torvelinho de ímpeto convexo;

dormindo rodopias, e te alagas

num turbilhão de diálogos sem nexo.

Sonâmbula parada, és a andarilha,

ilhada entre lençóis. Virgem tens prole,

pois é ao mesmo tempo avó, mãe e filha.

E que o sono múltiplo te viole,

anjo desnudo, salamandra de asas

ressuscitada de dormidas brasas.

O Livro de Sonetos se associará de forma direta ao "Barco bêbado" de Rimbaud, autor lido por Jorge de Lima e que lhe fornece uma concepção poética que prima pelo onirismo, pela desarticulação da linguagem e pela criação livre. Rimbaud também foi o poeta que mais inspirou a vanguarda surrealista. Tendência estética que Jorge de Lima estabelece um diálogo frutífero em sua poesia final. Assim, como também Camões com Os Lusíadas. Dessa forma, o poeta funda uma relação inusitada entre dois procedimentos poéticos antagônicos, o que mostra o projeto poético (a mistura entre razão e inspiração e posteriormente, em Invenção de Orfeu, a mistura do poema curto ao épico) de Jorge de Lima, revelado na "nau" que é o seu próprio poema.

Vamos meu duplo-mor às índias e ao país do Preste-João desconhecido. Partamos em ignorada rota blau por mar de Páscoa sob o céu renhido.

Olha-me a face: acaso essa ébria nau não tem velame e tempo, nem ouvido? Acaso essa ventura não tem vau ou árduo cabo Não inadvertido?

Já preparaste a treva e o pesadelo, 
a mão sob a cabeça, o óleo profundo, o rei de Calicute e o de Melinde?

Ah! a nau opaca em sombra e seu modelo vão desvendar a ausência desse mundo em que a poesia a túnica não cinde.

O Livro de Sonetos, em síntese, parece apontar para o desejo mítico do poeta de encontrar ou retomar o início dos tempos, o tempo primordial, antes da Queda em que o mundo inicial - o paraíso perdido - seria recuperado.

\author{
Imaginai no firmamento de antes \\ dois nevoeiros em oito entrelaçados, \\ galo e penumbra, draga sempre em púbis \\ penetradas de proa dominantes. \\ E a calmaria toda havia há instantes \\ em círculo de sal e cios porfiados. \\ Desce a baba dos cabos bojadores \\ Sobe a ilha em vermelhos tão agudos. \\ A brisa em nascimento cai em chuva, \\ abrem-se os ventres da água primitiva, \\ logo embebidos, logo despejados. \\ Cordilheiras parindo coisas como. \\ E outros montes mais virgens dividindo-se. \\ E Deus babando sobre o mundo do início.
}

É interessante notar, no primeiro verso do poema, que o desejo de encontrar o mundo paradisíaco, como o mundo inicial no momento de sua criação, se mostra e/ou se realiza por meio da figuração do símbolo do infinito em "dois nevoeiros em oito entrelaçados,", juntamente com sua memória da infância que nesse momento também carrega o sentido de memória ancestral e mítica.

O sentimento poético se contrapõe à passagem do tempo inexorável e destruidor de tudo. Neste momento, a poesia, recupera o passado como se conseguisse materializar e/ou armazenar o tempo perdido em seus versos. Dessa forma, a passagem do tempo para o poeta é vista de maneira negativa, pois é por causa desse movimento temporal que tudo se destrói e se acaba. Assim, os bons momentos do passado, principalmente os relacionados à infância, tanto ao passado infantil do poeta quanto ao referente à infância da humanidade - que de acordo com a ideologia cristã representa o tempo anterior à Queda - são buscados na tentativa de se alcançar a eternidade. 
Como vimos, a expressão poética de Jorge de Lima no Livro de Sonetos pode ser notada de maneira privilegiada em três principais modos: a inspiração, o trabalho técnico e a memória. A primeira liga o procedimento poético do autor de $A$ túnica inconsútil ao onirismo, como é característico da estética surrealista, a partir dos seus diversos desdobramentos: na utilização da colagem, na metáfora construída por meio de associações de elementos díspares, na utilização mesma do sonho como elemento que propicia o impulso poético e também do imaginário noturno. No segundo momento, a expressão onírica ganha ainda um sentido mais profundo em sua poética, pois corresponde à própria concepção do "fazer poético", que se atém à inspiração para criação de seus poemas, mas não no sentido simplista de deixar o "correr da pena" sem que haja o apuro da linguagem. 0 exercício poético também está intrinsecamente ligado ao controle de sua criação, mesmo o poeta se utilizando de forma privilegiada do imaginário. É como nos diz de Octavio Paz: "O sonho do poeta exige, numa camada mais profunda, a vigília; e esta, por sua vez, acarreta o abandono ao sonho." (PAZ, 1982, p.202). E, como também o próprio poeta revelará posteriormente em Invenção de Orfeu, com a metáfora do "engenheiro noturno". Expressão que rompe com a aparente oposição e/ou separação entre razão e inspiração para a criação artística. Nesse sentido, quebra-se a ideia de que existem apenas dois tipos de possibilidades criativas: aquela em que o artista criaria somente por meio da inspiração e a outra, em que a criação seria feita apenas por meio da razão. 0 "engenheiro noturno" é exemplar como expressão metafórica, pois abarca duas características paradoxais do mesmo ser. 0 engenheiro, que no exercício de sua profissão se utiliza do cálculo e da técnica para realização de seu trabalho, é por excelência o indivíduo que faz uso da ciência e da matemática para conceber e realizar sua obra. Contrário a esse tipo de concepção criadora, está o elemento "noturno" que em um sentido mais imediato representa o mundo do sono, do sonho, do devaneio, contrastando, assim, com o primeiro elemento. Mas na poética de Jorge de Lima essa união de elementos opostos, que inicialmente pode parecer paradoxal, na realidade, representa a maneira pela qual o poeta elabora sua criação poética. Unido os contrários, elementos que normalmente seriam incompatíveis e antagônicos, o poeta utiliza-se do elemento racional e do onírico para realização poética. Em síntese, a metáfora do "engenheiro noturno" aponta para a ideia que, no seu poema, unem-se os campos intelectual e espiritual, que se exprimem numa linguagem 
engenhosa e onírica. É interessante notar que essa caracterização do "fazer poético" presente em Invenção de Orfeu, representa a própria concepção moderna do "fazer poético" que oscila entre o delírio e a razão, representada, de um lado, por Rimbaud e, de outro, por Mallarmé e Valéry, e que se encontra amalgamada em Baudelaire, centro dessas duas correntes principais da poesia moderna. No terceiro momento, Jorge de Lima utiliza-se da memória em seu sentido ancestral, proveniente da figa mítica da Musa, o que revela o desejo do poeta em reencontrar o "paraíso perdido", ou seja, o tempo original em que a palavra primordial está situada.

Diante disso, torna-se cada vez mais claro, na obra de Jorge de Lima, um desejo expresso de retorno à inocência, à pureza e ao tempo original. Em uma espécie de sonho com a existência primordial, o poeta se afasta do tempo presente devastado pelas contingencias de sua modernização. Dessa forma, o Livro de Sonetos anuncia Invenção de Orfeu, momento em que a lírica de Jorge de Lima se voltará totalmente para o mito, para o escatológico e para o mistério da criação poética.

\section{Referências}

ANDRADE, Fábio de Souza. O engenheiro noturno: A lírica final de Jorge de Lima. São Paulo: EDUSP, 1997.

ANDRADE, Fábio de Souza. A musa quebradiça. In: BOSI, Alfredo (org.). Leitura de poesia. São Paulo, Ática, 1996.

ARAÚJO, Jorge de Souza. Jorge de Lima e o idioma poético afro-nordestino. Maceió: EDUFAL, 1983.

BOSI, Viviana. A imagem na poesia: Jorge de Lima. Leitura do soneto $\mathrm{X}$, canto $\mathrm{X}$ de Invenção de Orfeu. In: BOSI, Viviana. Et. Alli (orgs.). O Poema: Leitores e leituras. Cotia São Paulo: Ateliê editorial, 2001.

CARNEIRO, J. Fernando. Apresentação de Jorge de Lima. Rio de Janeiro: MEC, 1958.

CUNHA, Fausto. Nota preliminar. In: LIMA Jorge de. Obra Completa (org. Afrânio Coutinho). Rio de Janeiro: Aguilar, 1958.

DUTRA, Waltensir. Descoberta, Integração e Plenitude de Orfeu. In:_Poesia Completa: volume único (org. Alexei Bueno; textos críticos, Marco Lucchesi... [et al.].). Rio de Janeiro: Nova Aguilar, 1997.

ELIADE, Mircea. Mito e realidade. São Paulo: Ed. Perspectiva, 1998. 
FREUD, Sigmund. A interpretação dos sonhos. Rio de Janeiro: Imago, 2001.

LIMA Jorge de. Obra Completa (org. Afrânio Coutinho). Rio de Janeiro: Aguilar, 1958.

LINS, Álvaro. Poesia e Forma. In: Teoria Literária. Rio de Janeiro, Ediouro: 1970.

PAUlinO, Ana Maria. Jorge de Lima - Artistas Brasileiros (Poesia e Pintura). São Paulo: EDUSP, 1995.

PAZ, Octávio. A Inspiração. In: O Arco e a lira. Rio de Janeiro: Nova Fronteira, 1982.

RAYMOND, Marcel. De Baudelaire ao surrealismo. São Paulo: EDUSP, 1997.

VERNANT, J. P. Aspectos míticos da memória e do tempo. In: Mito e pensamento entre os gregos: estudos de psicologia histórica. Rio de Janeiro: Paz e Terra, 1990.

Recebido em março de 2014.

Aceito em junho de 2014. 